Potravinarstvo Slovak Journal of Food Sciences

vol. 15, 2021, p. 528-535

https://doi.org/10.5219/1553

Received: 22 January 2021. Accepted: 23 March 2021.

Available online: 28 June 2021 at www.potravinarstvo.com

(C) 2021 Potravinarstvo Slovak Journal of Food Sciences, License: CC BY 4.0

ISSN 1337-0960 (online)

\title{
THE MICRONUTRIENT PROFILE OF MEDICINAL PLANT EXTRACTS
}

\author{
Marija Zheplinska, Mikhailo Mushtruk, Volodymyr Vasyliv, Anatolii Kuts, Natalia Slobodyanyuk, \\ Larysa Bal-Prylypko, Mykola Nikolaenko, Olena Kokhan, Yuriy Reznichenko, Oksana Salavor
}

\begin{abstract}
Medicinal plants contain biologically active substances that have a physiological effect on the human body. In the territory of Ukraine, 15 of the most important medicinal plants grow from a medical point of view, among which are Melissa officinalis $\mathrm{L}$ and Calendula officinalis. Micronutrients are necessary for the body in small quantities, not being a source of energy, they take part in their assimilation, as well as in the regulation of various functions and the implementation of the processes of growth and development of the human body. The study aims to establish the micronutrient profile of extracts and infusions from medicinal raw materials - Calendula officinalis and Melissa officinalis. The established micronutrient profile includes data on the content of such macro- and microelements as calcium, potassium, sodium, iron, zinc, and copper in extracts and infusions from Melissa officinalis L officinalis L and Calendula officinalis. Sodium predominates from certain macronutrients, the superiority of which is manifested in Calendula officinalis when infused. A large amount of calcium also passes into the aqueous-alcoholic infusion from Calendula officinalis. Copper and zinc prevail among the determined microelements in water extracts of Calendula officinalis. Comparing the results obtained, we can say in the affirmative about the micro- and macro elements that have passed into extracts that Calendula officinalis is richer in these substances. Because infusions and extracts are recommended to be added as an additional ingredient to vegetable and fruit juices, their positive infusion on the human body will increase the recommended daily requirement of potassium and sodium. Based on the results of this study, extracts and infusions of Melissa officinalis L and Calendula officinalis can be considered as an essential source of micronutrients for enriching fruit and vegetable juices in canned food for health purposes.
\end{abstract}

Keywords: micronutrients; biologically active substances; extract; Calendula officinalis; Melissa officinalis L

\section{INTRODUCTION}

The body is not able to synthesize trace elements and makes up for their deficiency only from food, therefore trace elements are irreplaceable, and their absence or excess causes the development of many diseases (Ebid, 2015). For thousands of years, people have received mineral elements only with food in an organically bound form. The entire system of digestion, active transport, and assimilation of our body is focused precisely on the consumption of organically bound macro- and microelements. This system not only controls the assimilation process, depending on the needs of the body at a given moment but also has a mechanism for the accumulation of vital organically "connected elements in special" cellular depots (Liaqat et al., 2016).

Unfortunately, our system of consumption of elements is not at all adapted to the assimilation of inorganic compounds and salts of various elements that enter our body with water, food, air as a product of technogenic pollution (Mushtruk et al., 2020a). For the same reason, due to the inadequacy of our assimilation system and the absence of special mechanisms for assimilation, transport, and accumulation, in most cases inorganic forms of macro- and microelement compounds have an extremely low toxicity threshold and, at the slightest excess of the dosage, cause severe intoxication of all vital organs and systems. That is why, for example, preparations of inorganic iodine and selenium are prescribed only under medical supervision (Park and Kim, 2016).

Preparations containing inorganic microelements are prescription pharmaceuticals and are taken only under medical supervision. Extracts and infusions of biologically active substances from medicinal raw materials, compensate for the deficiency of macro- and microelements, contain, as a rule, only organically bound elements, are not able to harm the body even with thoughtless and incorrect use (Waheed et al., 2018).

The peculiarity of extracts and infusions from medicinal plants is that their biologically active substances are in a certain ratio, contributing to the optimal effect on the human body. Some components of plant extracts are similar in chemical structure to physiologically active substances of the body (hormones, vitamins, enzymes, etc.). Therefore, such natural medicines are more actively involved in the biochemical processes of the human body together with juices (Sheiko et al., 2019). 
The need to fortify food with micro- and microelements is dictated by objective changes in the lifestyle, set, and nutritional value of the food used in food (Mushtruk et al., 2020b). To provide the human body with the necessary micronutrients, food should be varied, and products are rich in biologically active substances, therefore, the addition of extracts and infusions to any juice will allow the use of beverages in food that significantly restore human health and reduce various diseases.

\section{Scientific hypothesis}

Is to determine some micro- and macroelements in medicinal plants, data for which are not available in the literature, to create tables of the chemical composition of medicinal plants. There is an assumption that Calendula officinalis is richer in substances that were determined by tests, due to their intense coloration. Studies of the number of micronutrients of extracts and infusions from Melissa officinalis L and Calendula officinalis should be carried out using flame photometry and spectrometry methods for their exact amounts. Surely the transition of micronutrients into infusions and extracts will also be different due to the different

\section{MATERIAL AND METHODOLOGY}

For research, we took medicinal raw materials Calendula officinalis and Melissa officinalis L. Calendula flowers and melissa leaves were used for research. According to the manufacturer, the plants were collected at the initial stage of flowering. Dried and ready for research raw materials were purchased in a pharmacy network. For experimental studies, the raw material was ground on a laboratory crusher. Then added aqueous and aqueousalcoholic solutions at hydromodule 1 , ie the same amount of raw material and extractant. Extraction of micronutrients or their infusion was carried out according to the methods presented in the research results.

\section{Chemicals}

Distilled water $\left(\mathrm{H}_{2} \mathrm{O}\right)$ for extraction, it was pre-purified in an aqueous distiller. The electrical conductivity of manufactured distilled water meets the national standard of laboratory distilled water of the first level and can be used in medicine and everyday life.

Ethanol $\left(\mathrm{C}_{2} \mathrm{H}_{5} \mathrm{OH}\right.$, producer «Inter-Synthesis» Limited Liability Company, Ukraine, chemically pure for analysis).

Sodium chloride ( $\mathrm{NaCl}$, producer «Inter-Synthesis» Limited Liability Company, Ukraine, chemically pure for analysis).

Potassium chloride (KCl, producer «Inter-Synthesis» Limited Liability Company, Ukraine, chemically pure for analysis).

Calcium carbonate $\left(\mathrm{CaCO}_{3}\right.$, producer «Inter-Synthesis» Limited Liability Company, Ukraine, chemically pure for analysis).

The above anhydrous salts were used to make reference solutions and to construct calibration graphs of macronutrient content.

\section{Animals and Biological Material}

Medicinal raw materials (Melissa officinalis $\mathrm{L}$ and Calendula officinalis) for research (provided by Natalia farm, Khmelnytsky region, Shepetivka district).

\section{Instruments}

Automated refractometer (Anton Paar, producer «InterSynthesis» Limited Liability Company, Ukraine). By which the dry matter content was determined.

The thermometer is laboratory (TLS-200, producer «InterSynthesis» Limited Liability Company, Ukraine).

Surfactometer (Saturn-4, producer «Inter-Synthesis» Limited Liability Company, Ukraine). By which the content of trace elements was determined.

Flame photometer (BWB Technologies, producer «InterSynthesis» Limited Liability Company, Ukraine).

\section{Laboratory Methods}

Determination of dry matter content was carried out according to ISO 2173:2003 (2003). The method of flame photometry is based on the construction of a calibration graph. It is used when the composition of the sample and the approximate amount of interfering ions are known. This makes it possible to bring the composition of the reference solutions as close as possible to the composition of the determined samples. Quantitative determination of elements by flame, photometry is possible only in the presence of reference solutions.

For the determination of macroelements, the flame photometry method was used, which is an arbitration method for the determination of metals in food products.

Emission photometry is based on the method of constructing a calibration graph. It is used when the composition of the sample is known, and the approximate amount of ion interferes. This makes it possible to maximally approximate the composition of the standard solutions to the composition of the samples to be determined. Standard solutions were prepared from standard solutions by dilution. Water was used as an extract, and a 20\% aqueous-alcoholic solution was used for infusion.

Reference solutions are solutions (samples) in which the content of the element to be determined is known with sufficient accuracy. Reference solutions were prepared from standard solutions by diluting them. The starting materials for the preparation of reference solutions are double-distilled water and anhydrous chemically pure salts of the brand "HC" or $\mathrm{NaCl}, \mathrm{KCl}$, and $\mathrm{CaCO}_{3}$. The calculated amount of salt was weighed on an analytical balance to the nearest $0.0001 \mathrm{~g}$ and dissolved in a volumetric flask. For each solution (both reference and determined) took 5 readings of the device and found the average value.

Calibration graphs were constructed in the coordinates:

$$
I=f(C)
$$

where: I is the current on the microammeter (instrument readings), $\mu \mathrm{A}$;

$\mathrm{C}$ is the concentration of the solution, $\mu \mathrm{g} \cdot \mathrm{mL}^{-1}$.

The number of the element in the sample was determined according to the schedule. Determination of trace elements using the atomic absorption method was carried out according to GOST 30178 (1996) (Table 1).

\section{Description of the Experiment}

Sample preparation: Two samples of medicinal raw materials were used for research - Melissa officinalis L and 
Calendula officinalis, which were purchased at the pharmacy.

Number of samples analyzed: During the experimental research, 20 different samples (Melissa officinalis L and Calendula officinalis) of one manufacturer purchased in different pharmacy chains were examined.

Number of repeated analyses: All measurements of instrument, readings were performed 5 times.

Number of experiment replication: The number of repetitions of each experiment to determine one value was also 5 times.

\section{Statistical Analysis}

Mathematical and statistical processing of experimental data was carried out in determining the criteria of Cochran's $\mathrm{C}$ test, Fisher, and Student's $t$-test. The accuracy of the data was determined using the Cochrane criterion, and the adequacy of the mathematical model was checked using the Fisher and Student criteria. Statistical processing was performed in Microsoft Excel 2016 values were estimated using mean and standard deviations and subsequently evaluated in the statistical program XL Stat. In hypothesis testing, if the $p$-value is lower than significant level, in case of XL Stat software by Addinsoft (version 2019.3.2), it is 0.05, the null hypothesis was rejected and alternativehypothesis was confirmed.

\section{RESULTS AND DISCUSSION}

The established micronutrient profile includes data on the content of such macro- and microelements as calcium, potassium, sodium, iron, zinc, and copper in extracts and infusions from Melissa officinalis L and Calendula officinalis. Sodium predominates from certain macronutrients, the superiority of which is manifested in Calendula officinalis when infused. A large amount of calcium also passes into the aqueous-alcoholic infusion from Calendula officinalis. Copper and zinc prevail among the determined microelements in water extracts of Calendula officinalis. The following scientists were engaged in similar researches in works (Spiegler, Liebau and Hensel, 2017; Teanpaisan et al., 2017) investigated the process of extraction of Matricaria recutita, and in works (Tiwary et al., 2017; Veni, Pushpanathan and Mohanraj, 2017) similar process of Plantago lanceolata was investigated.

Comparing the results obtained, we can say in the affirmative about the micro- and macro elements that have passed into extracts that Calendula officinalis is richer in these substances. Because infusions and extracts are recommended to be added as an additional ingredient to vegetable and fruit juices, their positive infusion on the human body will increase the recommended daily requirement for potassium and sodium by $4-5 \%$, calcium by $2-3 \%$, iron by $15-17 \%$, zinc, and copper up to $20 \%$ with a portion of the drink in the amount of $0.00025 \mathrm{~m}^{3}$.

Before starting the experiments, the raw material was preliminarily crushed for better transfer of the raw material substances into the extract or infusion. When using water, the crushed raw material was subjected to an increase in temperature from $20-70{ }^{\circ} \mathrm{C}$, determining the dry matter content every 10 minutes (Figure 1). In scientific works (Bazarnova et al., 2017; Bezerra et al., 2018), temperature regimes above $70{ }^{\circ} \mathrm{C}$ were used, and the dry matter content was recognized after the completion of the process, which in our opinion can lead to mixing of dry matter content. After 40 minutes from the beginning of the experiments, the dry matter content did not increase, which indicates swollen raw materials. In this case, the hydronic modulus was 1 . Therefore, it was decided to carry out the extraction process by maintaining the mixture for some time and at a certain temperature. These two factors will be the main ones in the process of the conducted research.

For the transfer of extractives from medicinal raw materials to the extract, the temperature range was taken from $40-60{ }^{\circ} \mathrm{C}$. The authors of scientific works (Konovalenko and Polovko, 2019; Florea et al., 2020) took the temperature range from $30-40{ }^{\circ} \mathrm{C}$, applying the settling process for 24 hours, which in our opinion can lead to mixing of dry matter content.

As seen in Figure 2 at a temperature of $60^{\circ} \mathrm{C}$ and keeping such an extract at 60 minutes, the value of the dry matter content is of the greatest importance, and the continuation of experiments does not make sense. The authors of scientific works (Makasana et al., 2017; Ranjith, 2018; Mamadalieva et al., 2019; D'Auria, Mecca and Todaro, 2020) performed similar experiments at a temperature of $75^{\circ} \mathrm{C}$ and for 2 hours but the maximum dry matter yield is in the range of $6.5-7.2 \%$.

For another extractant of a water-alcohol solution, thanks to which fat-soluble substances can be extracted, a concentration of $20 \mathrm{wt} \%$ was taken. When using a wateralcohol solution, the temperature of the mixture was not increased, as it was done for water, since alcohol is a volatile substance. Measurements were carried out every 30 minutes and the dry matter content was determined over 2.5 hours. Based on the research results, curves were constructed for both medicinal plants (Figure 3). The authors of the following scientific papers (Ulusoy, Acıdereli and Tutar, 2017; Chronopoulou et al., 2019) investigated the extraction of fat-soluble substances at different concentrations of water-alcohol solution using the following ratios of water: alcohol 1: 3, 1: 6 and 1: 9. Melfi et al. (2018) and Rathi et al. (2017) investigated the extraction of fat-soluble substances using liquid and gas, such a process and its technological aspects will be covered in future research.

It is visible on the graph the transition of dry substances into infusions, and for Calendula officinalis, it took 2 hours for the dry matter content to increase to $9 \%$, and for Melissa officinalis $\mathrm{L}-1.5$ hours, but the maximum amount of dry matter was $8.8 \%$. Therefore, the best time regimen for infusion in a water-alcohol solution with a concentration of $20 \%$ wt. at hydro module 1 and a process temperature of $60{ }^{\circ} \mathrm{C}$ for Melissa officinalis L it is 1.5 hours, and for Calendula officinalis -2 hours. But the authors of scientific works (Gullón et al., 2017; Al-Snafi, 2020; Jadhav et al., 2020; Zhang et al., 2020) argue that the best time regimen for infusion in a water-alcohol solution with a concentration in the range of $5-15 \%$ wt. with a hydro module of $0.2-0.75$ and a process temperature of $45-55{ }^{\circ} \mathrm{C}$ for Melissa officinalis L and Calendula officinalis is $1-3$ hours but the maximum dry matter yield is in the range of $4.5-6.2 \%$. 
Table 1 Conditions for atomic absorption determination of elements.

\begin{tabular}{|c|c|c|c|}
\hline Element & $\begin{array}{c}\text { Resonance line } \\
\text { length, nm }\end{array}$ & $\begin{array}{l}\text { Spectral slit } \\
\text { width, } \mathrm{nm}\end{array}$ & $\begin{array}{c}\text { Concentration of solutions for } \\
\text { graduation, } \mu \mathrm{g} \cdot \mathrm{mL}^{-1}\end{array}$ \\
\hline Cu (II) (copper) & 324.7 & 0.1 & $0.5-4.0$ \\
\hline Zn (II) (zinc) & 213.9 & 0.5 & $0.1-2.0$ \\
\hline Fe (III) (iron) & 248.3 & 0.1 & $1-10$ \\
\hline
\end{tabular}

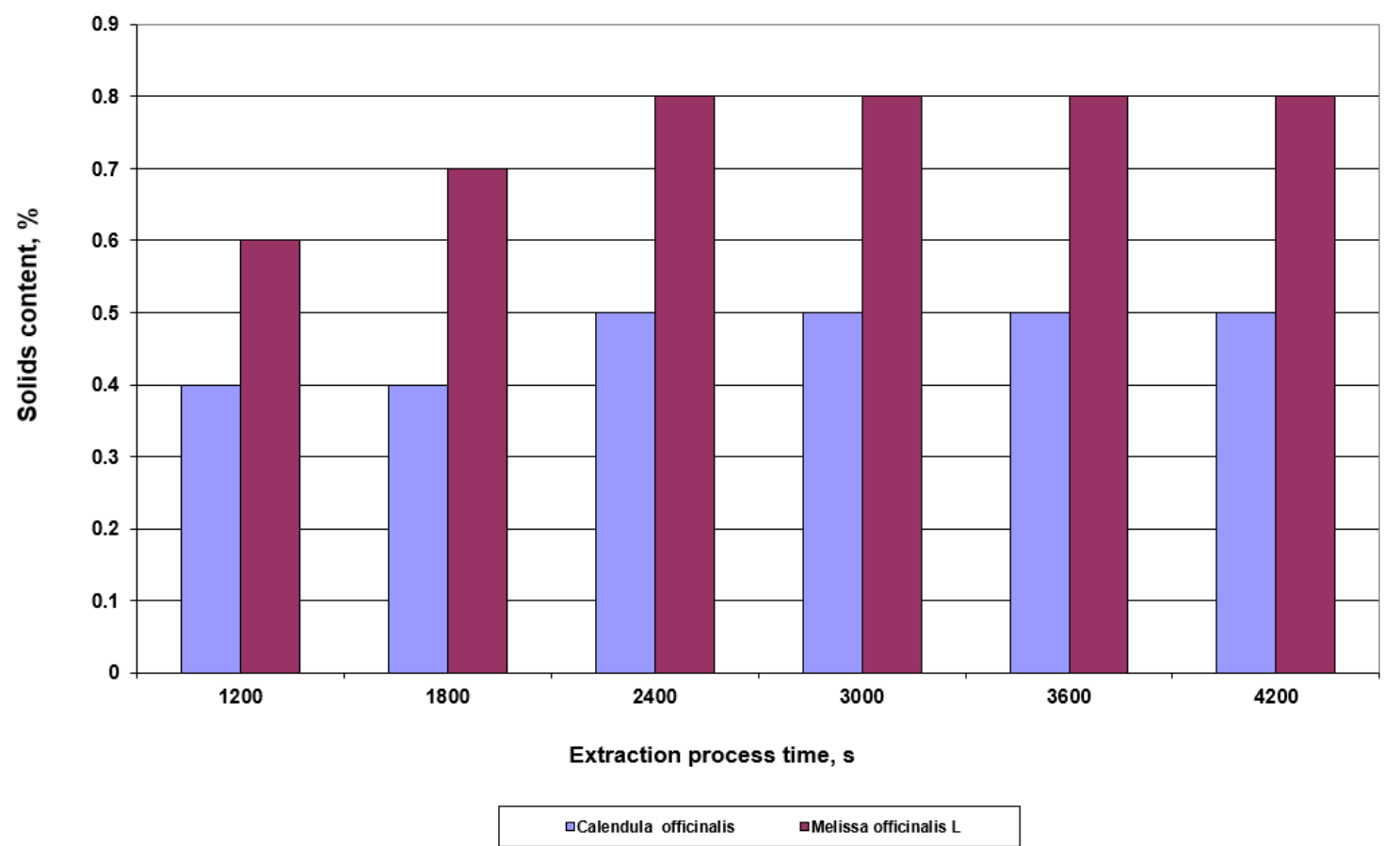

Figure 1 Change in the number of dry substances in medicinal raw materials with an increase in the duration of extraction.

Table 2 The content of macronutrients in extrtacts and infusions, $\mu g . \mathrm{mL}^{-1}$.

\begin{tabular}{ccccc}
\hline \multirow{2}{*}{ Element } & \multicolumn{2}{c}{ Water extract } & Water-alcohol infusion \\
\cline { 2 - 5 } & $\begin{array}{c}\text { Calendula } \\
\text { officinalis }\end{array}$ & Melissa officinalis $\mathbf{L}$ & $\begin{array}{c}\text { Calendula } \\
\text { officinalis }\end{array}$ & Melissa officinalis L \\
\hline K (potassium) & $1.5 \pm 0.01$ & $1.27 \pm 0.01$ & $1.2 \pm 0.01$ & $1.05 \pm 0.01$ \\
Ca (calcium) & $20 \pm 0.1$ & $16 \pm 0.05$ & $36 \pm 0.15$ & $23.5 \pm 0.1$ \\
Na (sodium) & $280 \pm 5$ & $148 \pm 3$ & $275 \pm 3$ & $12 \pm 1$ \\
\hline
\end{tabular}

Table 3 Content of trace elements in extracts and infusions, $\mu \mathrm{g} \cdot \mathrm{mL}^{-1}$.

\begin{tabular}{ccccc}
\hline \multirow{2}{*}{ Trace element } & \multicolumn{2}{c}{ Water extract } & \multicolumn{2}{c}{ Water-alcohol infusion } \\
\cline { 2 - 5 } & $\begin{array}{l}\text { Calendula } \\
\text { officinalis }\end{array}$ & Melissa officinalis $L$ & $\begin{array}{c}\text { Calendula } \\
\text { officinalis }\end{array}$ & Melissa officinalis L \\
\hline Zn (zinc) & $1.03 \pm 0.01$ & $0.3 \pm 0.01$ & $0.48 \pm 0.01$ & $0.23 \pm 0.01$ \\
Cu (copper) & $0.73 \pm 0.01$ & $0.18 \pm 0.01$ & $0.6 \pm 0.01$ & $0.2 \pm 0.01$ \\
Fe(III) (iron) & $3.8 \pm 0.015$ & $0.32 \pm 0.015$ & $0.2 \pm 0.01$ & $0.03 \pm 0.015$ \\
\hline
\end{tabular}




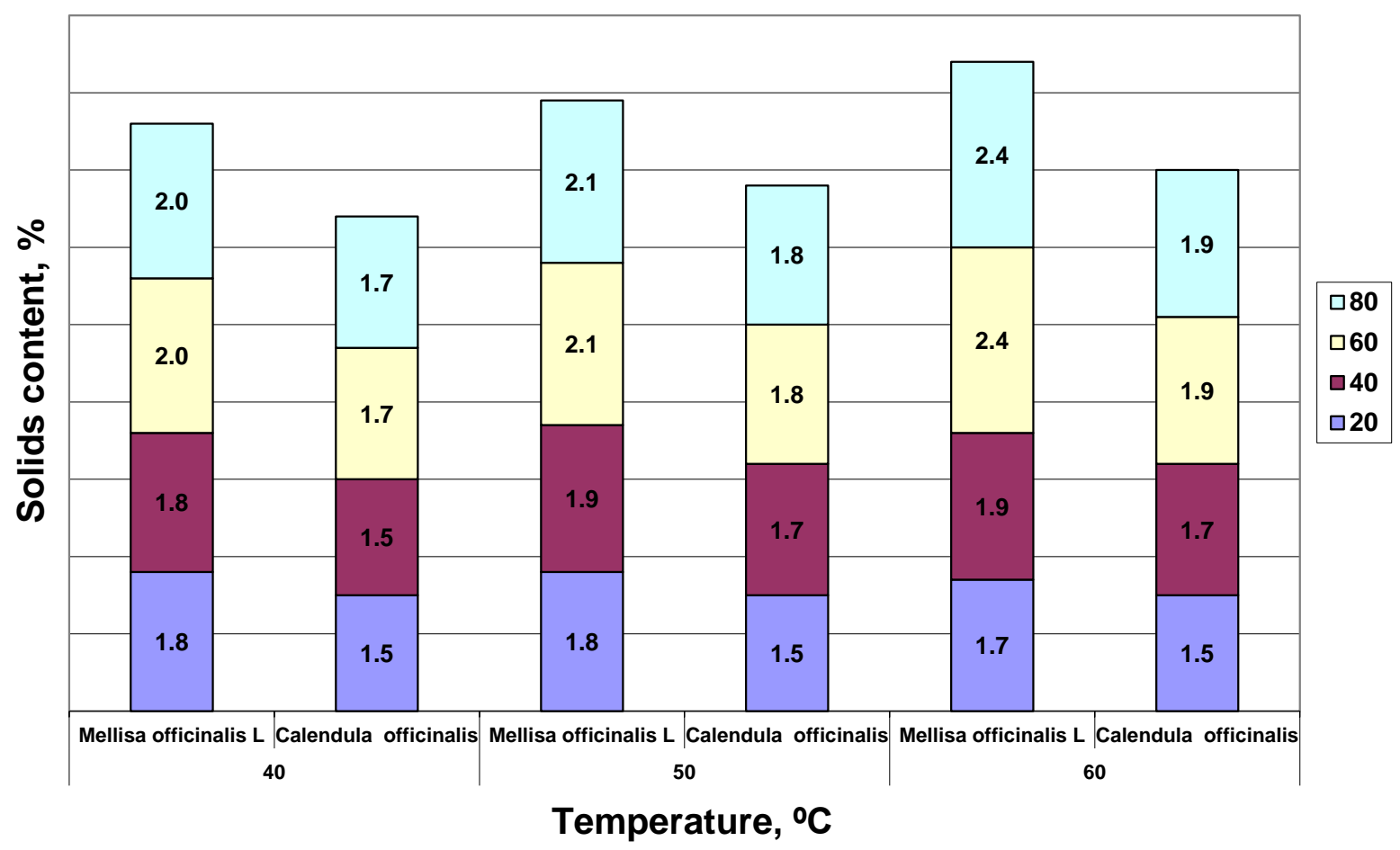

Figure 2 Change in the content of dry substances in medicinal raw materials with an increase in the duration of time at different temperatures.

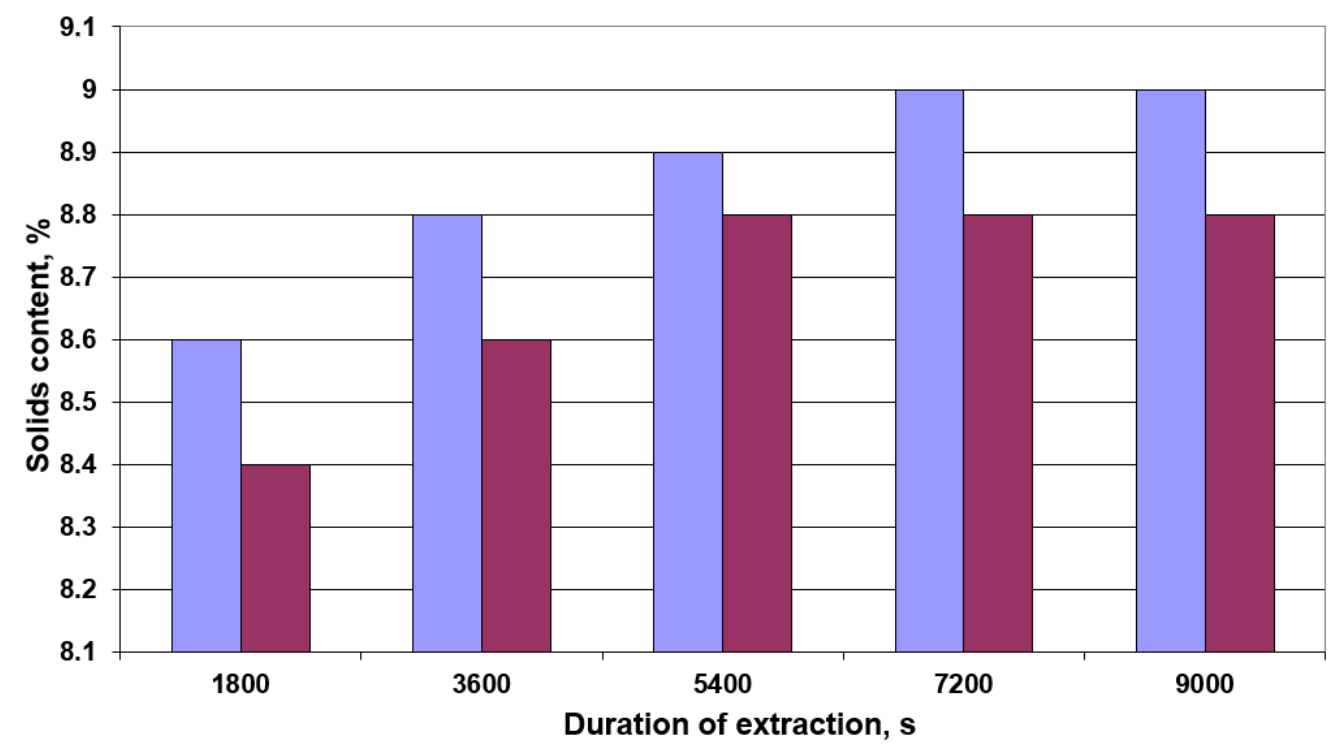

\begin{abstract}
$\square$ Calendula officinalis $\square$ Melissa officinalis $L$
\end{abstract}
Figure 3 Influence of the duration of infusion of medicinal raw materials in a water-alcohol solution on the dry matter content.

As shown by the results of our research (Table 2), at optimal parameters of extraction and infusion, the content of such macroelements as potassium, calcium, and sodium in aqueous and aqueous-alcoholic solutions slightly fluctuates, but the order remains the same. Except for the amount of sodium in Melissa officinalis L, more than 12 times more of this element passes into the aqueous extract, while calcium, on the contrary, is less for both Melissa officinalis L and Calendula officinalis.

Data analysis Table 3 indicates a higher content of the transferred zinc, copper, and iron in the aqueous extract than their amount in the aqueous-alcoholic solution. Especially noteworthy is a large amount of iron, which, after extraction, passes into an aqueous solution (19 times more). Considering that the necessary dose of all these substances is greater for the normal life of the human body, we can confidently talk about the benefits of using such extracts from Melissa officinalis L and Calendula officinalis, which will have a beneficial effect on the development and growth of the human body.

These data are consistent with the results of studies of the composition of macro- and microelements for medicinal raw materials and, in particular, lie within the data obtained at different extraction temperatures (Gupta et al., 2018; 
Bober et al., 2020). Among the micronutrients, the amounts of ascorbic acid were also determined, which passed into extracts and infusions from Calendula officinalis and Melissa officinalis L. Based on the results obtained, it can be argued that the maximum amount of this substance passes into the aqueous extract of Melissa officinalis, which corresponds to $6.2 \mathrm{mg} 100 \mathrm{~g}^{-1}$ after 1 hour of extraction. An increase in the amount of ascorbic acid in an aqueousalcoholic infusion of Melissa officinalis $\mathrm{L}$ up to $4.2 \mathrm{mg} .100 \mathrm{~g}^{-1}$ is also less important for 1 hour of infusion, but this amount is more than for the extract and infusion from Calendula officinalis by 56 and 55\%, respectively. The extraction time of ascorbic acid from Calendula officinalis was 1 hour, and the infusion time was 2 hours.

The composition of micronutrients in extracts and infusions from medicinal raw materials corresponds to the standards of consumption for adults recommended by the Food and Agriculture Organization of the United Nations and the World Health Organization (Zheplinska et al., 2020). The information provided in the micronutrient profile can be used for non-commercial communications and cannot be used for other purposes, including product labeling. The data obtained can be useful for creating tables of the chemical composition of extracts and infusions of such medicinal raw materials as Calendula officinalis and Melissa officinalis $L$. There is a need for further scientific research on this topic to determine other biologically active substances and generalize the results on the amount of these substances in extracts and infusions from medicinal raw materials. The relevance and novelty of the research are confirmed by obtaining patents of Ukraine for a useful model for vegetable drinks containing extracts and infusions from these types of medicinal raw materials (Palamarchuk et al., 2019; Zheplinska et al., 2019). Because infusions and extracts are recommended to be added as an additional ingredient to vegetable and fruit juices, their positive infusion on the human body will increase the recommended daily requirement of potassium and sodium by $4-5 \%$, calcium by $2-3 \%$, iron by $15-17 \%$, zinc, and copper up to $20 \%$ with a portion of the drink in the amount of $0.00025 \mathrm{~m}^{3}$.

\section{CONCLUSION}

The amounts of micronutrients of extracts and infusions from Melissa officinalis L and Calendula officinalis were investigated using flame photometry and spectrometry methods. The established micronutrient profile includes data on the content of such macro- and microelements as calcium, potassium, sodium, iron, zinc, and copper in extracts and infusions from Melissa officinalis L and Calendula officinalis. Sodium predominates from certain macronutrients, the superiority of which is manifested in Calendula officinalis when infused. A large amount of calcium also passes into the aqueous-alcoholic infusion from Calendula officinalis. Copper and zinc prevail among the determined microelements in water extracts of Calendula officinalis. Comparing the results obtained, we can say in the affirmative about the micro- and macro elements that have passed into extracts that Calendula officinalis is richer in these substances.

\section{REFERENCES}

Al-Snafi, A. E. 2020. Oils and fats contents of medicinal plants, as natural ingredients for many therapeutic purposes-A review. IOSR Journal of Pharmacy, vol. 10, no. 7, p. 1-41.

Bazarnova, N. G., Tikhomirova, L. I., Frolova, N. S., Mikushina, I. V. 2017. Isolation and analysis of extractives from white cinquefoil (Potentilla alba L.) grown under different conditions. Russian Journal of Bioorganic Chemistry, $\begin{array}{lllll}\text { vol. } 43, & \text { no. } & \text { 7, } & \text { p. } & \text { 752-759. }\end{array}$ https://doi.org/10.1134/S1068162017070032

Bezerra, I. C. F., Ramos, R. T. M., Ferreira, M. R. A., Soares, L. A. L. 2018. Chromatographic profiles of extractives from leaves of Eugenia uniflora. Revista Brasileira de Farmacognosia, vol. 28, no. 1, p. 92-101. https://doi.org/10.1016/j.bjp.2017.11.002

Bober, A., Liashenko, M., Protsenko, L., Slobodyanyuk, N., Matseiko, L., Yashchuk, N., Gunko, S., Mushtruk, M. 2020. Biochemical composition of the hops and quality of the finished beer. Potravinarstvo Slovak Journal of Food Sciences, vol. 14, no. 1, p. 307-317. https://doi.org/10.5219/1311

D'Auria, M., Mecca, M., Todaro, L. 2020. High temperature treatment allows the detection of episesamin in paulownia wood extractives. Natural Product Research, vol. 34, no. 9, p. 1326-1330. https://doi.org/10.1080/14786419.2018.1560289

Ebid, A. I. 2015. Anti-bacterial activity of folk medicinal plant extracts of Saudi Arabia on isolated bacteria. Journal of Applied Life Sciences International, vol. 3, no. 1, p. 49-54. https://doi.org/10.9734/JALSI/2015/16395

Florea, A. M., Drumea, V., Nita, R. A., Bicu, A., Olariu, L., Dutu, L. E., Gird, C. E. 2020. Transfer rate of pesticide residues from medicinal plants in different types of extractive solutions. Toxicological \& Environmental Chemistry, vol. 102, no. 1-4, p. 37-61. https://doi.org/10.1080/02772248.2020.1773466

ISO 2173:2003. Fruit and vegetable products Determination of soluble solids - Refractometric method.

GOST 30178:1996. Raw material and food-stuffs. Atomic absorption spectrometric method for determination of toxic elements.

Gullón, B., Lú-Chau, T. A., Moreira, M. T., Lema, J. M., Eibes, G. 2017. Rutin: A review on extraction, identification and purification methods, biological activities and approaches to enhance its bioavailability. Trends in Food Science \& Technology, vol. 67, p. 220-235. https://doi.org/10.1016/j.tifs.2017.07.008

Gupta, S., Jain, R., Kachhwaha, S., Kothari, S. L. 2018. Nutritional and medicinal applications of Moringa oleifera Lam.--Review of current status and future possibilities. Journal of Herbal Medicine, vol. 11, p. 1-11. https://doi.org/10.1016/j.hermed.2017.07.003

Chronopoulou, L., Dal Bosco, C., Di Caprio, F., Prosini, L., Gentili, A., Pagnanelli, F., Palocci, C. 2019. Extraction of carotenoids and fat-soluble vitamins from Tetradesmus Obliquus microalgae: an optimized approach by using supercritical $\mathrm{CO}_{2}$. Molecules, vol. 24, no. 14, 14 p. https://doi.org/10.3390/molecules24142581

Jadhav, A. S., Patil, O. A., Kadam, S., Bhutkar, M. A. 2020. Review on Aloe Vera is used in Medicinal Plant. Asian Journal of Research in Pharmaceutical Science, vol. 10, no. 1, p. 2630. https://doi.org/10.5958/2231-5659.2020.00006.5

Konovalenko, I., Polovko, N. 2019. Study of the influence of pharmaceutical factors on the optimization of the release of biologically active substances upon receipt the water extracts from gynecological plant medical collection. Annals of Mechnikov's Institute, no. 3, p. 50-53.

Liaqat, I., Pervaiz, Q., Bukhsh, S., Ahmed, S., Jahan, N. 2016. Investigation of bactericidal effects of medicinal plant 
extracts on clinical isolates and monitoring their biofilm forming potential. Pakistan Veterinary Journal, vol. 36, no. 2, p. $159-164$.

Makasana, J., Dholakiya, B. Z., Gajbhiye, N. A., Raju, S. 2017. Extractive determination of bioactive flavonoids from butterfly pea (Clitoria ternatea Linn.). Research on Chemical Intermediates, vol. 43, no. 2, p. 783-799. https://doi.org/10.1007/s11164-016-2664-y

Mamadalieva, N. Z., Böhmdorfer, S., Zengin, G., Bacher, M., Potthast, A., Akramov, D. K., Janibekov, A., Rosenau, T. 2019. Phytochemical and biological activities of Silene viridiflora extractives. Development and validation of a HPTLC method for quantification of 20-hydroxyecdysone. Industrial Crops and Products, vol. 129, p. 542-548. https://doi.org/10.1016/j.indcrop.2018.12.041

Melfi, M. T., Nardiello, D., Cicco, N., Candido, V., Centonze, D. 2018. Simultaneous determination of water- and fat-soluble vitamins, lycopene and beta-carotene in tomato samples and pharmaceutical formulations: Double injection single run by reverse-phase liquid chromatography with UV detection. Journal of Food Composition and Analysis, vol. 70, p. 9-17. https://doi.org/10.1016/j.jfca.2018.04.002

Mushtruk, M., Gudzenko, M., Palamarchuk, I., Vasyliv, V., Slobodyanyuk, N., Kuts, A., Nychyk, O., Salavor, O., Bober, A. 2020b. Mathematical modeling of the oil extrusion process with pre-grinding of raw materials in a twin-screw extruder. Potravinarstvo Slovak Journal of Food Sciences, vol. 14, p. 937-944. https://doi.org/10.5219/1436

Mushtruk, M., Vasyliv, V., Slobodaniuk, N., Mukoid, R., Deviatko, O. 2020a. Improvement of the Production Technology of Liquid Biofuel from Technical Fats and Oils. In Ivanov, V., Pavlenko, I., Liaposhchenko, O., Machado, J., Edl, M. Advances in Design, Simulation and Manufacturing III. Switzerland : Springer International Publishing, p. 377-386. ISBN 21954364-21954356. https://doi.org/10.5219/1436

Palamarchuk, I., Mushtruk, M., Vasyliv, V., Zheplinska, M. 2019. Substantiation of regime parameters of vibrating conveyor infrared dryers. Potravinarstvo Slovak Journal of Food Sciences, vol. 13, no. 1, p. 751-758. https://doi.org/10.5219/1184

Park, J. H., Kim, I. H. 2016. Interactive effects of fenugreek (Trigonella foenum-graecum L.) seed extract supplementation and dietary metabolisable energy levels on the growth performance, total tract digestibility, blood profiles, and excreta gas emission in broiler chickens. Animal Production Science, vol. 56, no. 10, p. 1677-1682. https://doi.org/10.1071/AN14834

Ranjith, D. 2018. Fluorescence analysis and extractive values of herbal formulations used for wound healing activity in animals. Journal of Medicinal Plants Studies, vol. 6, no. 2, p. 189-192.

Rathi, D. N., Liew, C. Y., Fairulnizal, M. N. M., Isameyah, D., Barknowitz, G. 2017. Fat-soluble vitamin and carotenoid analysis in cooking oils by ultra-performance convergence chromatography. Food Analytical Methods, vol. 10, no. 4, p. 1087-1096. https://doi.org/10.1007/s12161-016-0661-9

Sheiko, T., Tkachenko, S., Mushtruk, M., Vasyliv, V., Deviatko, O., Mukoid, R., Bilko, M., Bondar, M. 2019. The Studying the processing of food dye from beet juice. Potravinarstvo Slovak Journal of Food Sciences, vol. 13, no. 1, p. 688-694. https://doi.org/10.5219/1152

Spiegler, V., Liebau, E., Hensel, A. 2017. Medicinal plant extracts and plant-derived polyphenols with anthelmintic activity against intestinal nematodes. Natural Product Reports, vol. 34, no. 6, p. 627-643. https://doi.org/10.1039/C6NP00126B
Teanpaisan, R., Kawsud, P., Pahumunto, N., Puripattanavong, J. 2017. Screening for antibacterial and antibiofilm activity in Thai medicinal plant extracts against oral microorganisms. Journal of Traditional and Complementary Medicine, vol. 7, no. 2, p. 172-177. https://doi.org/10.1016/j.jtcme.2016.06.007

Tiwary, B. K., Ghosh, R., Moktan, S., Ranjan, V. K., Dey, P., Choudhury, D., Dutta, S., Deb, D., Das, A. P., Chakraborty, R. 2017. Prospective bacterial quorum sensing inhibitors from Indian medicinal plant extracts. Letters in Applied Microbiology, vol. 65, no. 1, p. 2-10. https://doi.org/10.1111/lam.12748

Ulusoy, H. I., Acıdereli, H., Tutar, U. 2017. Optimization of extraction parameters for fat soluble vitamins and major element analysis in Polygonum cognatum Meissn plant (Madimak). Journal of the Turkish Chemical Society Section A: Chemistry, vol. 4, no. 1, p. 165-178. https://doi.org/10.18596/jotcsa.287323

Veni, T., Pushpanathan, T., Mohanraj, J. 2017. Larvicidal and ovicidal activity of Terminalia chebula Retz. (Family: Combretaceae) medicinal plant extracts against Anopheles stephensi, Aedes aegypti and Culex quinquefasciatus. Journal of Parasitic Diseases, vol. 41, no. 3, p. 693-702. https://doi.org/10.1007/s12639-016-0869-z

Waheed, S., Hasnain, A., Ahmad, A., Tarar, O. M., Yaqeen, Z., Ali, T. M. 2018. Effect of Botanical Extracts on Amino Acid and Fatty Acid Profile of Broiler Meat. Brazilian Journal of Poultry Science, vol. 20, no. 3, p. 507-516. https://doi.org/10.1590/1806-9061-2017-0651

Zhang, J., Wen, C., Zhang, H., Duan, Y., Ma, H. 2020. Recent advances in the extraction of bioactive compounds with subcritical water: A review. Trends in Food Science \& Technology, vol. 95, p. 183-195. https://doi.org/10.1016/j.tifs.2019.11.018

Zheplinska, M., Mushtruk, M., Kos, T., Vasyliv, V., Kryzhova, Y., Mukoid, R., Bilko, M., Kuts, A., Kambulova, Y., Gunko, S. 2020. The influence of cavitation effects on the purification processes of beet sugar production juices. Potravinarstvo Slovak Journal of Food Sciences, vol. 14, no. 1, p. 451-457. https://doi.org/10.5219/1284

Zheplinska, M., Mushtruk, M., Vasyliv, V., Deviatko, O. 2019. Investigation of the process of production of crafted beer with spicy and aromatic raw materials. Potravinarstvo Slovak Journal of Food Sciences, vol. 13, no. 1, p. 806-814. https://doi.org/10.5219/1183

\section{Funds:}

This research received no external funding.

\section{Acknowledgments:}

We would like to thank you to Dr. for Larysa BalPrylypko.

\section{Conflict of Interest:}

The authors declare no conflict of interest.

\section{Ethical Statement:}

This article does not contain any studies that would require an ethical statement. 


\section{Contact Address:}

Marija Zheplinska, The National University of Life and Environmental Sciences of Ukraine, Faculty of Food Technology and Quality Control of Agricultural Products, Department of Processes and Equipment for Processing of Agricultural Production, Heroes of Defense Str. 12 B, Kyiv, 03040, Ukraine, Tel.: +38(050)133-80-28,

E-mail: jeplinska@ukr.net

ORCID: https://orcid.org/0000-0002-7286-3003

*Mikhailo Mushtruk, The National University of Life and Environmental Sciences of Ukraine, Faculty of Food Technology and Quality Control of Agricultural Products, Department of Processes and Equipment for Processing of Agricultural Production, Heroes of Defense Str. 12 B, Kyiv, 03040, Ukraine, Tel.: +38(098)941-26-06,

E-mail: mixej.1984@ukr.net

ORCID: https://orcid.org/0000-0002-3646-1226

Volodymyr Vasyliv, The National University of Life and Environmental Sciences of Ukraine, Faculty of Food Technology and Quality Control of Agricultural Products, Department of Processes and Equipment for Processing of Agricultural Production, Heroes of Defense Str. 12 B, Kyiv, 03040, Ukraine, Tel.: +38(097)465-49-75,

E-mail: vasiliv-vp@ukr.net

ORCID: https://orcid.org/0000-0002-2109-0522

Anatolii Kuts, The National University of Food Technology, Educational and Scientific Institute of Food Technology, Department of biotechnology of fermentation and wine-making products, Volodymyrska Str. 68, 01601 Kyiv, Ukraine, Tel.: +38(044)287-91-55,

E-mail: ag@ukr.net

ORCID: https://orcid.org/0000-0002-0207-7613

Natalia Slobodyanyuk, The National University of Life and Environmental Sciences of Ukraine, Faculty of Food Technology and Quality Management of Agricultural Products, Department of Technologies of Meat, Fish and Marine Products, Heroes of Defense Str. 15, 03041, Kyiv, Ukraine, Tel.: +380982768508,

E-mail: slob2210@ukr.net

ORCID: https://orcid.org/0000-0002-7724-2919
Larysa Bal-Prylypko, The National University of Life and Environmental Sciences of Ukraine, Faculty of Food Technology and Quality Management of Agricultural Products, Department of Technologies of Meat, Fish and Marine Products, Polkovnika Potekhina, Str. 16, 03041 Kyiv, Ukraine, Tel.: +380674018672,

E-mail: bplv@ukr.net

ORCID: https://orcid.org/0000-0002-9489-8610

Mykola Nikolaenko, The National University of Life and Environmental Sciences of Ukraine, Faculty of Food Technology and Quality Management of Agricultural Products, Department of Technologies of Meat, Fish and Marine Products, Polkovnika Potekhina Str. 16, 03041 Kyiv, Ukraine, Tel.: +380994096549,

E-mail: mykola.nikolaenko.nubip@gmail.com ORCID: https://orcid.org/0000-0003-2213-4985

Olena Kokhan, The National University of Food Technologies, Educational and Scientific Institute of Food Technology, Department of bakery and confectionery products, Volodymyrska Str. 68, 01601 Kyiv, Ukraine, Tel.: +38(097)793-93-88,

E-mail: eagavva@gmail.com

ORCID: https://orcid.org/0000-0003-4582-0814

Yuriy Reznichenko, The National University of Food Technologies, Educational and Scientific Institute of Food Technology, Department of Biotechnology and Microbiology, Volodymyrska Str. 68, 01601 Kyiv, Ukraine, Tel.: (044) 287-91-23,

E-mail: btec.nuft@gmail.com

ORCID: https://orcid.org/0000-0002-2732-2881

Oksana Salavor, The National University of Food Technology, Educational and Scientific Institute of Food Technology, Department of Environmental Safety, Volodymyrska Str. 68, 01601 Kyiv, Ukraine, Tel.: +38 (044) 287-91-55,

E-mail: saloksamir@ukr.net

ORCID: https://orcid.org/0000-0002-5784-3127

Corresponding author: * 